\title{
An Affinity Chromatographic Reactor for Highly Efficient Turnover of Dissociable Cofactors ${ }^{\dagger}$
}

\author{
Osato MiYawaKi, Kozo NAKamura and Toshimasa Yano \\ Department of Agricultural Chemistry, The University of Tokyo, \\ Bunkyo-ku, Tokyo 113, Japan \\ Received October 23, 1984
}

\begin{abstract}
A conjugated enzyme system of alcool dehydrogenase and lactate dehydrogenase was immobilized in an ultrafiltration hollow fiber tube, which was inserted in a fine nylon tube to form a hollow-fiber-capillary reactor. To this reactor, the substrates, pyruvate and ethanol, were supplied continuously. The necessary cofactor, NAD, was supplied as a pulse for a short time. The retention time of NAD in the reactor, estimated from the response curve of lactate produced, was much longer than those of the other substrates and products because of the strong adsorption of NAD to the immobilized enzymes through affinity. Therefore, the reactor could produce lactate from pyruvate for a long time without any more NAD. As a typical case, when the enzyme concentration is sufficiently high, the estimated retention time of NAD was 50 times as long as those of other materials so that the NAD turnover obtained was 412,000 . The effects of NAD pulse concentration and the immobilized enzyme concentration on the retention time of NAD and NAD turnover were investigated experimentally and theoretically.
\end{abstract}

To construct a bioreactor for the enzymatic synthesis of useful materials, the efficient regeneration of expensive dissociable cofactors such as NAD, NADP and ATP is necessary. Extensive work has been done on the regeneration of NAD because this cofactor is ubiquitous and involved in many reactions. To regenerate NAD, three methods were at tempted; chemical, ${ }^{1)}$ electrochemical ${ }^{2,3)}$ and enzymatic. ${ }^{4)}$ Among these three, the enzymatic method seems most promising because of its high reaction rate and excellent specificity. In this method, NAD is recycled by a conjugated enzyme system.

For a continuous reactor with continuous cofactor recycling, Chambers et al. ${ }^{5)}$ immobilized both NAD and the enzymes in a hollow fiber membrane, the cut-off molecular weight of which was smaller than that of NAD. However, since the molecular weight of NAD is 663 , compatibility of good permeability of the membrane for substrates and products with a sharp rejection of NAD seems difficult.

Gestrelius et $a l^{6}{ }^{6}$ immobilized NAD on alcohol dehydrogenase itself to make the cofactor a prosthetic group of the enzyme. The immobilized NAD, however, worked only with the conjugated oxidoreduction of two substrates, both of which were catalyzed only by the alcohol dehydrogenase and did not work in a conjugated enzyme system combined with lactate dehydrogenase because the steric hindrance obstructed the interaction between the NAD immobilized on alcohol dehydrogenase and the free lactate dehydrogenase.

Extensive work has also been done on chemically modified NAD bound to a water soluble macromolecule such as dextran. ${ }^{7)}$ Various methods were used for the chemical modification of $\mathrm{NAD}^{8 \sim 13)}$ and the macromolecule-bound-NAD was coimmobilized with the conjugated enzymes in a membrane reactor, ${ }^{14,15)}$ in a microcapsule ${ }^{16)}$ or in a gel. ${ }^{17)}$ Wichmann et al. ${ }^{18)}$ applied this meth-

$\dagger$ Presented in part at the Annual Meeting of the Agricultural Chemical Society of Japan, April, 1982 and at the 16th Autumn Meeting of the Society of Chemical Engineers, Japan, October, 1982. 
od for the continuous production of optically active 2-hydroxycarbonic acid, obtaining a good cofactor turnover of 69,400 . Although this cofactor turnover is fairly high, the coenzymatic activity, the stability and the cost of the macromolecule-bound-NAD still seem to be problems in this method.

Recently, we found that dissociable cofactors without any chemical modification could be continuously recycled very efficiently in a hollow fiber reactor in which the conjugated enzymes were immobilized at a high concentration. The cofactor was not bound to any macromolecule but fed continuously at a concentration lower than those of the enzymes. Through the affinity between the enzymes and the cofactor, the cofactor was concentrated locally around the immobilized enzymes. A very high turnover of the cofactor was expected theoretically, ${ }^{19)}$ and proved experimentally for a conjugated system of alcohol dehydrogenase and lactate dehydrogenase which needed NAD as a dissociable cofactor. ${ }^{20}$ ) Similarly, NADP was produced from NAD with ATP recycling. ${ }^{21)}$ In these cases, the reactor was a complete mixing type and the enzymes were immobilized physically in hollow fibers.

To use the affinity between the enzymes and the cofactor more efficiently, an affinity chromatographic reactor can be considered where the highly concentrated conjugated enzyme system is immobilized in a column type reactor. To this reactor the substrates are fed continuously and the cofactor to be recycled is supplied as a pulse. Because of the affinity with the enzymes, the retention time of the cofactor must be much longer than those of substrates and products, so that very high turnover of the cofactor can be expected. In addition, the cofactor is easily recovered because it exists as a pulse in the column. Thus, one may call this an affinity chromatographic reactor. In this paper, we applied this principle for the recycling of NAD by an immobilized conjugated enzyme system of alcohol dehydrogenase and lactate dehydrogenase.

\section{MATERIALS AND METHODS}

Materials. Bovine heart L-lactate dehydrogenase (EC 1.1.1.27, abbreviated as $\mathrm{LDH}$ hereafter) was obtained from Sigma Chemical Co. Yeast alcohol dehydrogenase (EC 1.1.1.1, abbreviated as $\mathrm{ADH}$ ) and $\beta$-NAD were obtained from Boehringer Mannheim Yamanouchi Co. All the other chemicals were of reagent grade.

Reactor. ADH and LDH were physically entrapped and immobilized in a hollow fiber tube (Asahi Kasei HC, nominal cut-off molecular weight $=13,000,0.8 \mathrm{~mm}$ in inner diameter, $1.4 \mathrm{~mm}$ in outer diameter, $1440 \mathrm{~mm}$ in length). The hollow fiber tube with the immobilized enzymes was inserted in a silicon tube (same length as the hollow fiber tube, 2.0 or $2.5 \mathrm{~mm}$ in inner diameter) to form a hollow-fiber-capillary reactor, which can be considered as a column type reactor (Fig. 1). The immobilization of the enzymes and the change of enzyme loading were very easy with this reactor. The permeability of the hollow fiber membrane was high enough to allow the diffusion of NAD, substrates and products rapidly as compared with the retention time of these materials in the reactor $^{20)}$ (3.4 4.2 hr for the substrates and products). The reactor was immersed in a water bath controlled at $25^{\circ} \mathrm{C}$. Substrates $(0.05 \mathrm{M}$ pyruvate and $0.835 \mathrm{M}$ ethanol in $0.05 \mathrm{M}$ Tris-buffer of $\mathrm{pH} 8$ ) were fed continuously with a peristaltic pump and NAD was supplied as a pulse for $20 \mathrm{~min}$. In the reactor, ADH catalyzed the reaction of ethanol with $\mathrm{NAD}^{+}$to produce acetaldehyde and NADH which reacted with pyruvate to produce lac-

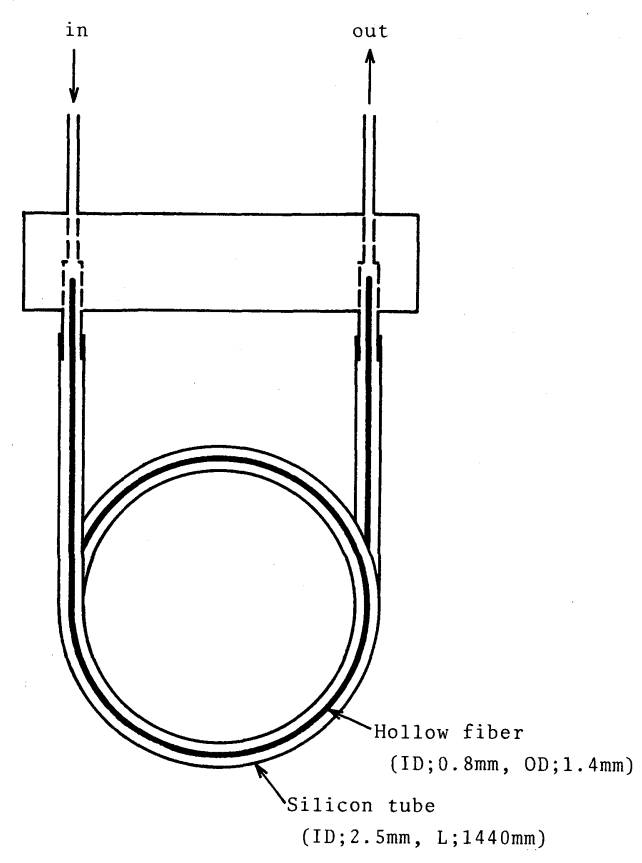

FIG. 1. Hollow-fiber-capillary Reactor. 


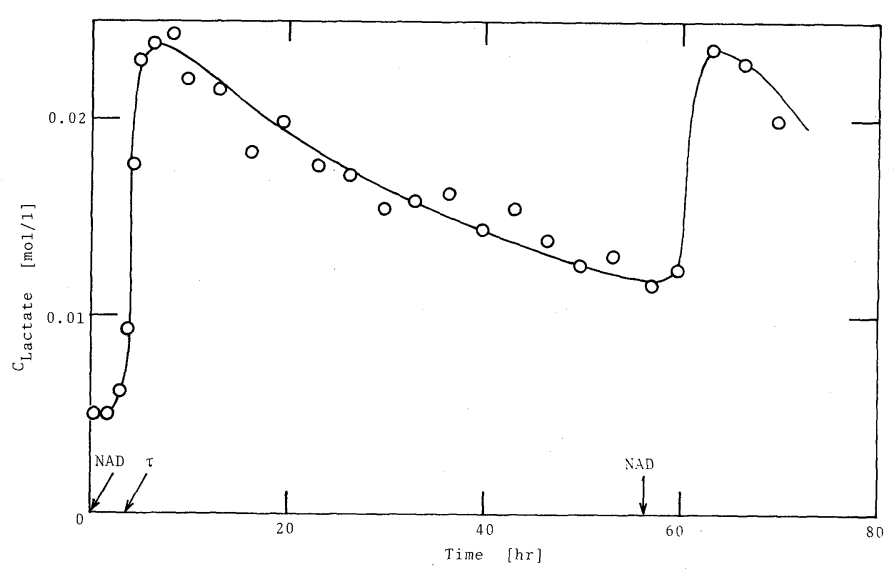

FIG. 2. Pulse Response of Affinity Chromatographic Reactor.

$\bar{e}_{\mathrm{ADH}}=2.99 \times 10^{-5} \mathrm{~mol} /$ liter; $\bar{e}_{\mathrm{ADH}} / \bar{e}_{\mathrm{LDH}}=1.63 ; \tau=3.63 \mathrm{hr} ; C_{\mathrm{NAD}}^{\text {pulse }}=5 \times 10^{-5} \mathrm{~mol} /$ liter; $\Delta t_{\mathrm{NAD}}^{\text {pulse }}=20 \mathrm{~min}$.

tate with the aid of $\mathrm{LDH}$. The effluent from the reactor was collected with a fraction collector and the lactate produced was assayed enzymatically as described previously. ${ }^{20)}$ The enzyme concentrations were calculated based on a molecular weight of 141,000 with two active sites for $\mathrm{ADH}^{22)}$ and a molecular weight of 150,000 with four active sites for $\mathrm{LDH}^{23}$ )

\section{RESULTS}

Figure 2 shows a response of the hollowfiber-capillary reactor to the pulse injection of NAD at time zero. In the reactor, the mean enzyme concentration of $\mathrm{ADH}$ was $2.99 \times 10^{-5} \mathrm{~mol}$ of active site per liter and the concentration ratio of the two enzymes, $\bar{e}_{\mathrm{ADH}} / \bar{e}_{\mathrm{LDH}}$, was 1.63 . The production of lactate was observed shortly after the injection of an NAD pulse at $5 \times 10^{-5} \mathrm{~mol} /$ liter. The peak in the lactate concentration produced, $C_{\text {Lac }}^{\text {peak }}$, was observed $4.1 \mathrm{hr}$ after the pulse injection of NAD and was $0.0243 \mathrm{~mol} /$ liter. The half-value period, $\tau_{1 / 2}$, defined as the time between the NAD pulse injection and the time when the response curve of lactate produced attained one half of the peak value, was $57 \mathrm{hr} . \tau_{1 / 2}$ was considered to be the mean residence time of NAD in the reactor because at this time approximately half of the given NAD remained in the reactor. A direct measurement of the retention time of NAD was unsuccessful because of its low concentration. The retention time for the substrates and products, $\tau$, measured by a step response of pyruvate, was $3.4 \mathrm{hr}$. The comparison of $\tau_{1 / 2}$ with $\tau$ made it clear that NAD stayed in the reactor much longer than the other materials because of its affinity with the immobilized enzymes. NAD turnover in the reactor, $\mathrm{R}_{\mathrm{N}}$, was 79,000. $R_{\mathrm{N}}$ was calculated as following

$$
R_{\mathrm{N}}=C_{\mathrm{Lac}}^{\text {peak }} \Delta t_{1 / 2} / C_{\mathrm{NAD}}^{\text {pulse }} / \Delta t_{\mathrm{NAD}}^{\text {pulse }}
$$

where $\Delta t_{1 / 2}$ is the half-width of the response curve of lactate produced and $\Delta t_{\mathrm{NAD}}^{\text {pulse }}$ is the pulse duration of NAD, which was $20 \mathrm{~min}$ in this case. In Fig. 2, the NAD pulse was injected again $56 \mathrm{hr}$ after the first injection. The peak height in the second response curve was almost the same as that of the first response curve, showing the apparent good stability of the immobilized enzyme system.

In Fig. 3, $\bar{e}_{\mathrm{ADH}}$ was increased to $1.48 \times$ $10^{-4} \mathrm{~mol} /$ liter with $\bar{e}_{\mathrm{ADH}} / \bar{e}_{\mathrm{LDH}}$ of 3.16 . Then, $\tau_{1 / 2}$ was as long as $213 \mathrm{hr}, 50$ times that of $\tau$ ( $=4.2 \mathrm{hr}$ ), and $R_{\mathrm{N}}$ obtained was as high as 412,000 .

Figure 4 shows the effect of $C_{\mathrm{NAD}}^{\text {pulse }}$ on the response curve with a fixed enzyme concen-

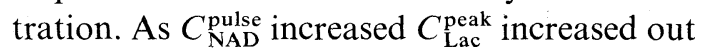
of proportional to $C_{\mathrm{NAD}}^{\text {pulse }}$. The dimensionless half-value period, $\tau_{1 / 2} / \tau$, decreased with an increase in $C_{\mathrm{NAD}}^{\text {pulse }}$. As a result, $R_{\mathrm{N}}$ increased with a decrease in $C_{\mathrm{NAD}}^{\text {pulse }}$. 


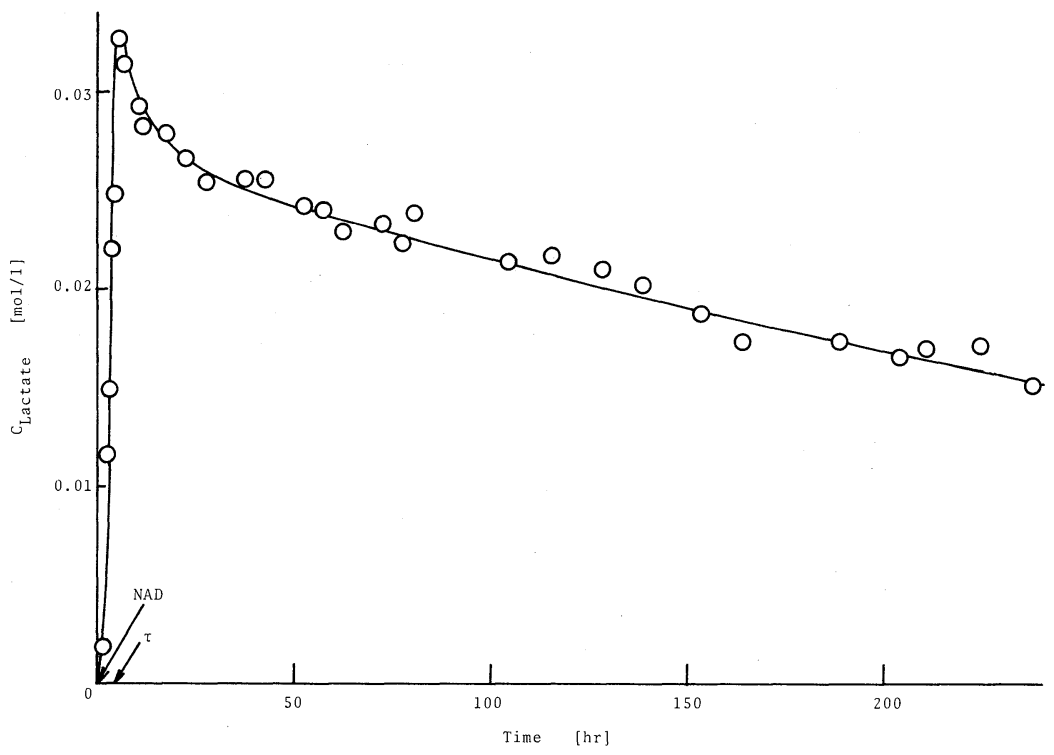

FIG. 3. Pulse Response of Affinity Chromatographic Reactor When Enzyme Concentration Is High. $\bar{e}_{\mathrm{ADH}}=1.48 \times 10^{-4} \mathrm{~mol} / \mathrm{liter} ; \bar{e}_{\mathrm{ADH}} / \bar{e}_{\mathrm{LDH}}=3.16 ; \tau=4.24 \mathrm{hr} ; C_{\mathrm{NAD}}^{\text {pulse }}=5 \times 10^{-5} \mathrm{~mol} /$ liter; $\Delta t_{\mathrm{NAD}}^{\text {pulse }}=20 \mathrm{~min}$.

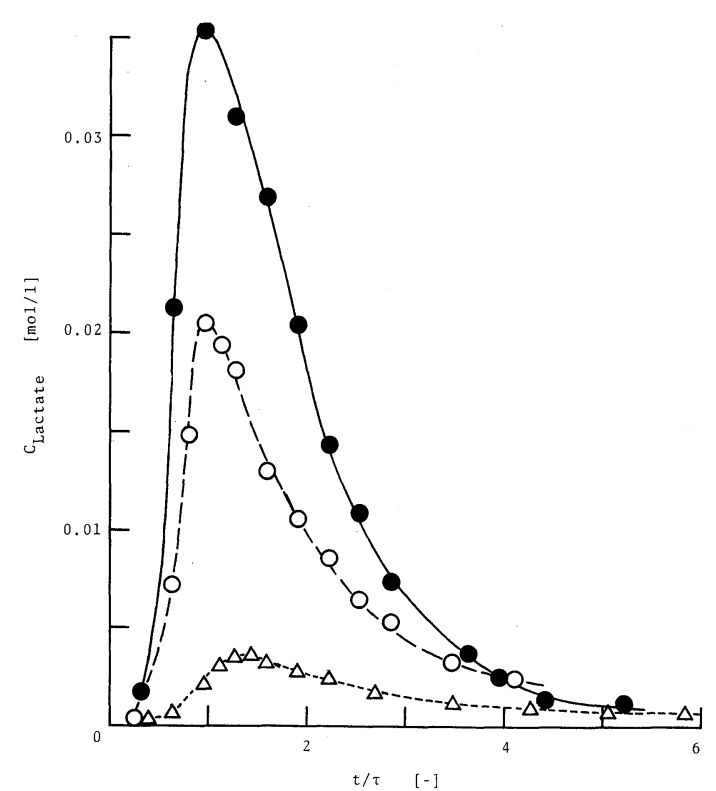

FIG. 4. Effect of NAD Pulse Intensity on Response Curve of Lactate Produced.

$\bar{e}_{\mathrm{ADH}}=6.66 \times 10^{-6} \mathrm{~mol} / \mathrm{liter} ; \bar{e}_{\mathrm{ADH}} / \bar{e}_{\mathrm{LDH}}=1.63 ; \tau=4.24 \mathrm{hr}$; $\Delta t_{\mathrm{NAD}}^{\text {pulse }}=20 \mathrm{~min} . \quad---\triangle^{---}, \quad C_{\mathrm{NAD}}^{\text {pulse }}=5 \times 10^{-6} \mathrm{~mol} /$ liter; $-\mathrm{O}-, \quad C_{\mathrm{NAD}}^{\mathrm{pulse}}=5 \times 10^{-5} \mathrm{~mol} /$ liter; $-\bigcirc-, \quad C_{\mathrm{NAD}}^{\mathrm{pulse}}=5 \times$ $10^{-4} \mathrm{~mol} / \mathrm{liter}$.

Figure 5 shows the effects of $C_{\mathrm{NAD}}^{\text {pulse }}$ on $\tau_{1 / 2} / \tau$ and $R_{\mathrm{N}}$. The dimensionless half-value period of the response curve of the lactate produced

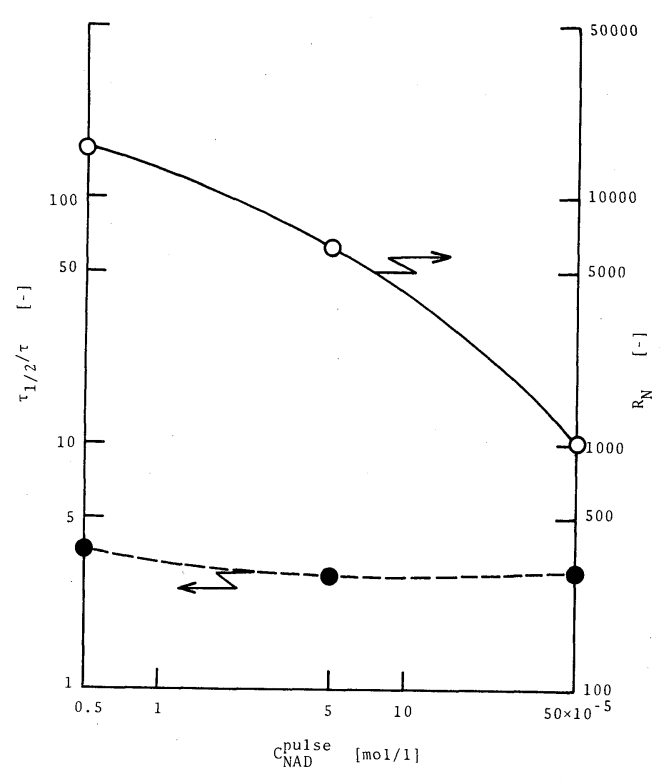

FIG. 5. Effects of NAD Pulse Intensity on Dimensionless Half-value Period and Turnover of NAD.

$\bar{e}_{\mathrm{ADH}}=6.66 \times 10^{-6} \mathrm{~mol} /$ liter; $\quad \bar{e}_{\mathrm{ADH}} / \bar{e}_{\mathrm{LDH}}=1.63 ; \Delta t_{\mathrm{NAD}}^{\text {pulse }}=$ $20 \mathrm{~min}$.

was significantly bigger than 1, suggesting that the retention time of NAD supplied as a pulse was much longer than those of the other materials because of its affinity with the enzymes immobilized. The dimensionless half- 


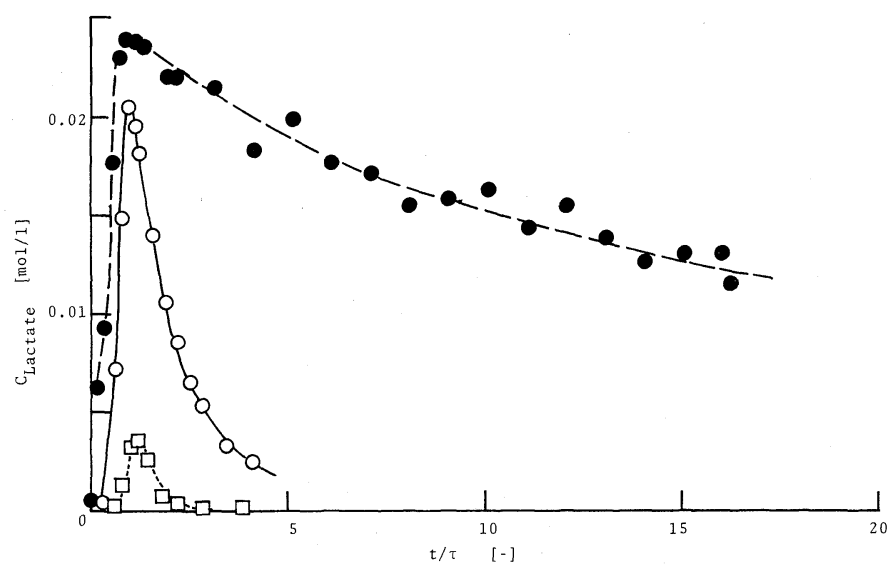

FIG. 6. Effect of Immobilized Enzyme Concentration on Response Curve of Lactate Produced.

$\bar{e}_{\mathrm{ADH}} / \bar{e}_{\mathrm{LDH}}=1.63 ; \quad C_{\mathrm{NAD}}^{\text {pulse }}=5 \times 10^{-5} \mathrm{~mol} /$ liter, $\Delta t_{\mathrm{NAD}}^{\text {pulse }}=20 \mathrm{~min} . \quad---\square---\bar{e}_{\mathrm{ADH}}=8.52 \times 10^{-7} \mathrm{~mol} / \mathrm{liter} ;-\bigcirc-$ $\bar{e}_{\mathrm{ADH}}=6.66 \times 10^{-6} \mathrm{~mol} / \mathrm{liter} ;--\frac{\bar{e}_{\mathrm{ADH}}}{}=2.99 \times 10^{-5} \mathrm{~mol} / \mathrm{liter}$.

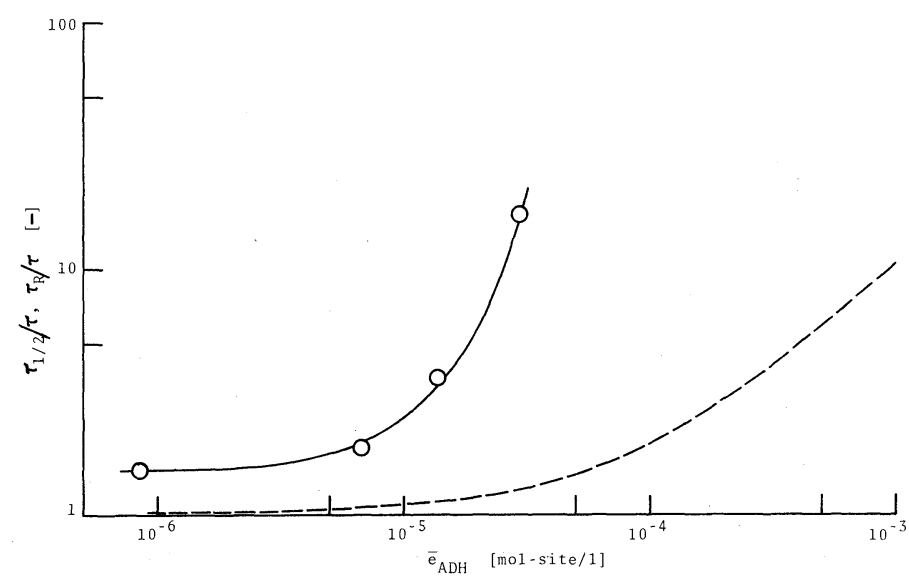

Fig. 7. Effect of Immobilized Enzyme Concentration on Dimensionless Half-value Period.

$\bar{e}_{\mathrm{ADH}} / \bar{e}_{\mathrm{LDH}}=1.63 ; C_{\mathrm{NAD}}^{\mathrm{pulse}}=5 \times 10^{-5} \mathrm{~mol} /$ liter; $\Delta t_{\mathrm{NAD}}^{\mathrm{pluse}}=20 \mathrm{~min} .-\mathrm{O}-, \tau_{1 / 2} / \tau ;----, \tau_{\mathrm{R}} / \tau$.

value period and the NAD turnover increased with a decrease in $C_{\mathrm{NAD}}^{\text {pulse }}$. However, the increase in $R_{\mathrm{N}}$ with a decrease in $C_{\mathrm{NAD}}^{\text {pulse }}$ was inevitably accompanied by a decrease in the conversion from pyruvate to lactate. So, practically a lower limit of $C_{\mathrm{NAD}}^{\text {pulse }}$ existed if a certain conversion was needed.

Figure 6 shows the effect of the immobilized enzyme concentration on the response curve of the lactate produced with fixed $\bar{e}_{\mathrm{ADH}} / \bar{e}_{\mathrm{LDH}}$ $(=1.63)$ and $C_{\mathrm{NAD}}^{\text {pulse }}\left(=5 \times 10^{-5} \mathrm{~mol} / \mathrm{liter}\right)$. With an increase in the enzyme concentration, $\tau_{1 / 2} / \tau$ and $R_{\mathrm{N}}$ increased greatly. When $\bar{e}_{\mathrm{ADH}}$ was $2.99 \times 10^{-5} \mathrm{~mol} /$ liter, $\tau_{1 / 2} / \tau$ reached 16.9 , which suggested that the retention time of NAD in the reactor was 16.9 times as long as those of other materials.

In Fig. $7, \tau_{1 / 2} / \tau$ was plotted against $\bar{e}_{\mathrm{ADH}}$ with fixed $\bar{e}_{\mathrm{ADH}} / \bar{e}_{\mathrm{LDH}}$ and $C_{\mathrm{NAD}}^{\text {pulse }} \tau_{1 / 2} / \tau$ increased acceleratively with an increase in the immobilized enzyme concentration, especially when the enzyme concentration was higher than $C_{\mathrm{NAD}}^{\text {pulse }}\left(=5 \times 10^{-5} \mathrm{~mol} /\right.$ liter $)$. As Fig. 8 shows, $R_{\mathrm{N}}$ also increased acceleratively with an increase in the enzyme concentration when the enzyme concentration was higher than $C_{\mathrm{NAD}}^{\text {pulse }}$ 


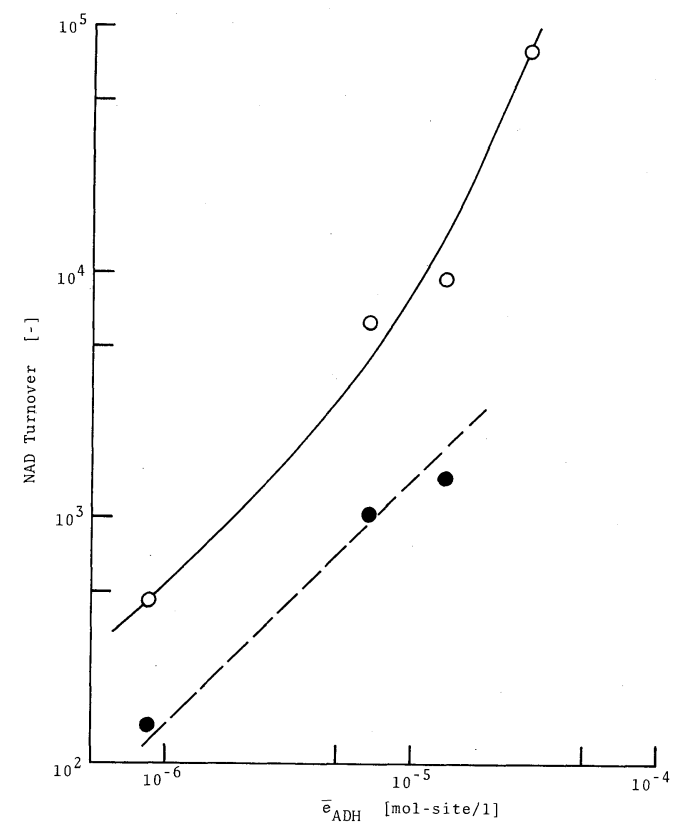

FIG. 8. Effect of Immobilized Enzyme Concentration on NAD Turnover.

$\bar{e}_{\mathrm{ADH}} / \bar{e}_{\mathrm{LDH}}=1.63 ; \quad \Delta t_{\mathrm{NAD}}^{\text {pulse }}=20 \mathrm{~min} . \quad-\bigcirc-, \quad C_{\mathrm{NAD}}^{\text {pulse }}=5 \times$ $10^{-5} \mathrm{~mol} /$ liter; - -,$C_{\mathrm{NAD}}^{\text {pulse }}=5 \times 10^{-4} \mathrm{~mol} /$ liter.

\section{DISCUSSION}

The effects of immobilized enzyme concentration and $C_{\mathrm{NAD}}^{\text {pulse }}$ on $\tau_{1 / 2} / \tau$ were investigated theoretically with the following assumptions. 1) The concentrations of substrates such as pyruvate and ethanol were so high that the effects of these concentrations on the enzyme kinetics were neglected. 2) The backward reactions were neglected for both enzymatic reactions of $\mathrm{ADH}$ and $\mathrm{LDH}$. 3) As for the mass transfer, rapid radial mixing and no axial dispersion were assumed. 4) Cha-Cha's equation was used to describe the enzyme kinetics because the enzyme concentrations were relatively high and not negligible compared with the concentrations of substrates $\left(\mathrm{NAD}^{+}\right.$and $\mathrm{NADH}$ ).

Then the system equation to describe the part of the reactor where the NAD pulse exists is:

$$
v=k_{\mathrm{ADH}} \bar{e}_{\mathrm{ADH}} C_{\mathrm{NAD}} /\left(K_{\mathrm{ADH}}^{\mathrm{NAD}}+C_{\mathrm{NAD}}+\bar{e}_{\mathrm{ADH}}\right)
$$

$$
\begin{gathered}
=k_{\mathrm{LDH}} \bar{e}_{\mathrm{LDH}} C_{\mathrm{NADH}} /\left(K_{\mathrm{LDH}}^{\mathrm{NADH}}+C_{\mathrm{NADH}}+\bar{e}_{\mathrm{LDH}}\right) \\
C_{\mathrm{NAD}}+C_{\mathrm{NADH}}=C_{\mathrm{NAD}}^{\text {pulse }}
\end{gathered}
$$

The rate parameters and the Michaelis constants in Eq. (2), obtained from the literature, ${ }^{23,24)}$ are:

$$
\begin{gathered}
k_{\mathrm{ADH}}=556 \mathrm{sec}^{-1} \\
k_{\mathrm{LDH}}=217 \mathrm{sec}^{-1} \\
K_{\mathrm{ADH}}^{\mathrm{NAD}}=1.19 \times 10^{-4} \mathrm{~mol} / \text { liter } \\
K_{\mathrm{LDH}}^{\mathrm{NADH}}=2.0 \times 10^{-5} \mathrm{~mol} / \text { liter }
\end{gathered}
$$

From Eqs. (2) and (3), $C_{\mathrm{NAD}}$ and $C_{\mathrm{NADH}}$ are calculated. Then the concentrations of the enzyme-cofactor complex are calculated:

$$
\begin{gathered}
{[\mathrm{AO}]=\bar{e}_{\mathrm{ADH}} C_{\mathrm{NAD}} /\left(K_{\mathrm{ADH}}^{\mathrm{NAD}}+C_{\mathrm{NAD}}+\bar{e}_{\mathrm{ADH}}\right)(8)} \\
{[\mathrm{LR}]=\bar{e}_{\mathrm{LDH}} C_{\mathrm{NADH}} /\left(K_{\mathrm{LDH}}^{\mathrm{NADH}}+C_{\mathrm{NADH}}+\bar{e}_{\mathrm{LDH}}\right)}
\end{gathered}
$$

where $[\mathrm{AO}]$ and $[\mathrm{LR}]$ are the concentrations of $\mathrm{ADH}_{-} \mathrm{NAD}^{+}$complex and LDH-NADH complex, respectively. The total amount of cofactor adsorbed on the immobilized enzyme is $[\mathrm{AO}]+[\mathrm{LR}]$ and the concentration of the free cofactor is $C_{\mathrm{NAD}}^{\text {pulse }}-[\mathrm{AO}]-[\mathrm{LR}]$. According to the theory in chromatography, the retention time of NAD, $\tau_{R}$, will be:

$$
\begin{gathered}
\tau_{\mathrm{R}} / \tau=1+[\text { Adsorbed cofactor }] /[\text { Free cofactor }] \\
=1+([\mathrm{AO}]+[\mathrm{LR}]) /\left(C_{\mathrm{NAD}}^{\mathrm{pulse}}-[\mathrm{AO}]-[\mathrm{LR}]\right)
\end{gathered}
$$

In Table $\mathrm{I}, \tau_{\mathbf{R}} / \tau$ calculated and $\tau_{1 / 2} / \tau$ observed are shown. $\tau_{\mathbf{R}} / \tau$ is also plotted in Fig. 7. In both cases, the theoretical model seems to explain the dependence of $\tau_{1 / 2} / \tau$ on $C_{\mathrm{NAD}}^{\text {pulse }}$ and the enzyme concentration to some extent. However, $\tau_{\mathrm{R}} / \tau$ differed greatly from $\tau_{1 / 2} / \tau$ quantitatively. Several reasons should be considered. First, $\tau_{1 / 2}$ is the half-value period measured from the product response. $\tau_{1 / 2}$ is expected to have a strong relationship with $\tau_{\mathbf{R}}$ but still it is not the retention time as $\tau_{\mathbf{R}}$ in its strict meaning. Second, Cha-Cha's model was used in the theore- 
Table I. Effects of Immobilized Enzyme ConcenTRATION AND NAD PULSE INTENSITY ON NAD RETENTION TIME; COMPARISON BETWEEN ObSERVEd and CAlculated Results

\begin{tabular}{|c|c|c|c|c|}
\hline $\begin{array}{c}\bar{e}_{\mathrm{ADH}} \\
{[\mathrm{mol} / \text { liter }]}\end{array}$ & $\begin{array}{c}\bar{e}_{\mathrm{ADH}} / \\
\bar{e}_{\mathrm{LDH}}\end{array}$ & $\begin{array}{c}C_{\mathrm{NAD}}^{\text {pulse }} \\
{[\mathrm{mol} / \mathrm{liter}]}\end{array}$ & $\left(\tau_{1 / 2} / \tau\right)_{\mathrm{obsd}}$ & $\left(\tau_{\mathrm{R}} / \tau\right)_{\mathrm{caIcd}}$ \\
\hline $8.52 \times 10^{-7}$ & 1.63 & $5 \times 10^{-5}$ & 1.51 & 1.009 \\
\hline $6.66 \times 10^{-6}$ & 1.63 & $5 \times 10^{-5}$ & 1.89 & 1.068 \\
\hline $1.37 \times 10^{-5}$ & 1.63 & $5 \times 10^{-5}$ & 3.63 & 1.139 \\
\hline $2.99 \times 10^{-5}$ & 1.63 & $5 \times 10^{-5}$ & 16.9 & 1.301 \\
\hline $1.48 \times 10^{-4}$ & 3.16 & $5 \times 10^{-5}$ & 50.2 & 1.882 \\
\hline $6.66 \times 10^{-6}$ & 1.63 & $5 \times 10^{-6}$ & 2.62 & 1.110 \\
\hline $6.66 \times 10^{-6}$ & 1.63 & $5 \times 10^{-4}$ & 1.97 & 1.011 \\
\hline
\end{tabular}

tical model. Cha-Cha's model cannot give the accurate concentration of enzyme-cofactor complex in Eqs. (8) and (9) especially when the Michaelis constant is low compared with the concentrations of enzymes and cofactor. Without Cha-Cha's equation, however, the concentration of enzyme-cofactor complex cannot be given explicitly as a function of the concentrations of enzymes and cofactor. Third, in the theoretical model, the Michaelis constants in Eqs. (2), (8), and (9) stand for both the kinetic parameters of the enzyme reactions and the dissociation constants of enzyme-cofactor complexes. As for the kinetic parameters, the values in the literature from Eqs. (4) to (7) were employed. The accuracy of these values were checked experimentally and the results were quite reasonable. However, the Michaelis constants as the kinetic parameters were measured at a very low enzyme concentration where the enzyme concentration was neglegible as compared with that of $\mathrm{NAD}^{+}$and NADH. The present situation is much different. The enzyme concentration is comparable or even higher than that of $\mathrm{NAD}^{+}$ or NADH. Therefore, the values of the Michaelis constants may be much different. Further studies are necessary considering these problems to improve the theoretical model.

The concept of the affinity chromatographic reactor is described here. The major difference between this and the conventional chromatographic reactor is that, in the former, the material to be adsorbed in the reactor is neither substrate nor product but a cofactor which is a part of the catalyst. The cofactor turnover obtained was surprisingly high in this system. Thus the cost of the cofactor will be very low because of its high turnover and no need for chemical modification, but the cost for the enzymes will be high because of its high concentration. Therefore, high stability will be needed for the immobilized enzymes. To reduce the enzyme cost, displacement of a part of enzymes with an appropriate adsorbent may be considered. To raise the cofactor turnover more, a recovery of the cofactor pulse injected must be considered. The corresponding project is under investigation.

\section{REFERENCES}

1) J. B. Jones and K. E. Taylor, J. Chem. Soc., Chem. Commun., 205 (1973).

2) R. W. Coughlin, M. Aizawa, B. F. Alexander and M. Charles, Biotech. Bioeng., 17, 515 (1975).

3) M. Aizawa, S. Suzuki and M. Kubo, Biochim. Biophys. Acta, 444, 886 (1976).

4) O. H. Lowry, J. V. Passonneau, D. W. Schulz and M. K. Rock, J. Biol. Chem., 236, 2746 (1961).

5) R. P. Chambers, J. R. Ford, J. H. Allender, W. H. Baricos and W. Cohen, "Enzyme Engineering," Vol. 2, ed. by E. K. Pye and L. B. Wingard, Jr., Plenum Press, New York, 1974, p. 195.

6) S. Gestrelius, M.-O. Mansson and K. Mosbach, Eur. J. Biochem., 57, 529 (1975).

7) K. Mosbach, P.-O. Larsson and C. Lowe, "Methods in Enzymology," Vol. 44, ed. by K. Mosbach, Academic Press, New York, 1976, pp. 859 887.

8) J. R. Wykes, P. Dunnill and M. D. Lilly, Biochim. Biophys. Acta, 286, 260 (1972).

9) M. Lindberg, P.-O. Larsson and K. Mosbach, Eur. J. Biochem., 40, 187 (1973).

10) M. Muramatsu, I. Urabe, Y. Yamada and H. Okada, Eur. J. Biochem., 80, 111 (1977).

11) Y. Sakaguchi and T. Murachi, J. Appl. Biochem., 2, 117 (1980).

12) A. F. Buckmann, M,-R. Kula, R. Wichmann and C. Wandrey, J. Appl. Biochem., 3, 301 (1981).

13) M. Yoshikawa, M. Goto, K. Ikura, R. Sasaki and H. Chiba, Agric. Biol. Chem., 46, 207 (1982).

14) P. Davies and K. Mosbach, Biochim. Biophys. Acta, 370, 329 (1974).

15) Y. Yamazaki, H. Maeda and H. Suzuki, Biotech. Bioeng., 18, 1761 (1976).

16) J. Grunwald and T. M. S. Chang, Biochem. Biophys. Res. Commun., 81, 565 (1978).

17) Y. Morikawa, I. Karube and S. Suzuki, Biochim. 
Biophys. Acta, 523, 263 (1978).

18) R. Wichmann. W. Hummel, H. Schutte, A. F. Buckmann, C. Wandrey and M.-R. Kula, Proceeding of 7 th Enzyme Engineering, White Haven, PA, September 25 30, 1983, p. 203.

19) O. Miyawaki, K. Nakamura and T. Yano, J. Chem. Eng. Japan, 15, 142 (1982).

20) O. Miyawaki, K. Nakamura and T. Yano, J. Chem. Eng. Japan, 15, 224 (1982).
21) O. Miyawaki, K. Nakamura and T. Yano, Agric. Biol. Chem., 46, 2725 (1982).

22) M. Dickinson, Eur. J. Biochem., 41, 31 (1974).

23) G. W. Schwert and A. D. Winer, "The Enzymes," 2nd Ed., Vol.7, ed. by P. D. Boyer, H. Lardy and K. Myrback, Academic Press, New York, 1963 pp. $127 \sim 148$.

24) C. J. Dickenson and F. M. Dickinson, Biochem. J., 147, 303 (1975). 